\title{
Determinants of livelihood strategy variation in two extractive reserves in Amazonian flooded and unflooded forests
}

\author{
PETER NEWTON ${ }^{1 *}$, WHALDENER ENDO ${ }^{2}$ AND CARLOS A. PERES ${ }^{1}$ \\ ${ }^{1}$ Centre for Ecology, Evolution and Conservation, School of Environmental Sciences, University of East Anglia, Normich NR4 7TF, UK, and \\ ${ }^{2}$ Department of Ecology and Natural Resource Management, Normegian University of Life Sciences, PO Box 5003, 1432 As, Norway \\ Date submitted: 28 March 2011; Date accepted: 2 September 2011; First published online: 21 December 2011
}

\section{SUMMARY}

Extractive reserves account for a significant proportion of the remaining intact forest within Brazilian Amazonia. Managers of extractive reserves need to understand the livelihood strategies adopted by rural Amazonians in order to implement projects that benefit the livelihoods of local residents whilst maintaining forest integrity. Whilst resident populations are often descended from immigrant rubber-tappers, dynamic economic and social conditions have led to a recent diversification of land-use practices. This two-year study in two large contiguous extractive reserves encompassing both unflooded (terra firme) and seasonally flooded (várzea) forest, shows the degree to which local livelihood strategies of different settlements are heterogeneous. Extractive offtake of forest products and fish catches and agricultural activities, together with income from sales, for 82 households in 10 communities were quantified in detail by means of weekly surveys. The survey data were combined with interviews to examine the demographic and wealth profile, and engagement in alternative activities, in 181 households across 27 communities. All households and communities were engaged in all three subsistence activity types, but there was large variation in engagement with income-generating activities. Households within a community showed considerable congruence in their income-generating activity profiles, but there was significant variation between communities. Yields from agriculture and fishing were more temporally stable than extraction of highly-seasonal forest products. Generalized linear mixed models showed that forest type was consistently important in explaining yields of both agrarian and extractive products. Communities with greater access to terra firme forest were inherently more agricultural, and strongly committed to manioc production. Communities with greater access to flooded forest, however, showed a greater dependence on fishing. Conservation should be more attuned to the diversity and dynamism of livelihood strategies in protected areas; in particular, reserve managers and policy

*Correspondence: Peter Newton Tel: +44 7877309564 e-mail: newton.pete@gmail.com makers should account for the effect of local variation in physical geography when designing sustainable development projects.

Keymords: agriculture, Amazonia, extractive reserve, fishing, flooded forest, heterogeneity, livelihoods, non-timber forest product, terra firme, várzea

\section{INTRODUCTION}

Developing rural livelihoods within protected areas is an important means of achieving conservation objectives in Amazonia (Campos \& Nepstad 2006). As part of this strategy, sustainable-development and multiple-use reserves (hereafter, collectively referred to as extractive reserves) currently account for over 14\% of Brazilian Amazonia, and are being created at a faster rate than traditional strictly-protected areas (ARPA [Programa Àreas Protegidas da Amazônia] 2010). Extractive reserves have been defined as forest areas inhabited by extractive populations granted long-term usufruct rights to forest resources which they collectively manage (Schwartzman 1989). As legally-occupied protected areas, extractive reserves aim to ensure the conservation of biodiversity and environmental services whilst providing opportunities for sustainable resource use (Allegretti 1990). The fate of Amazonian forests is therefore intricately associated with the lasting success of extractive reserves as an integrated conservation-development concept. In turn, the likelihood of such reserves achieving a balance between conservation aims and socioeconomic development is significantly influenced by the aggregate resource-use behavioural patterns of their residents (Takasaki et al. 2001).

Most non-tribal rural Amazonians were originally drawn to the region by the rubber booms of the late 19th and mid-20th centuries, when their principal income-generating activities were the extraction and sale of natural rubber (latex of Hevea spp.), Brazil nuts (seeds of Bertholletia excelsa) and the palatable latex of sorva (Couma spp.) (Dean 1987). However, extractive populations living in intact tropical forest regions have also traditionally exploited a diverse array of the available natural resources for both subsistence and commerce. The extraction of such forest products, which include a wide variety of plant and animal resources, is hugely important in subsidizing the household economies of millions of rural forest dwellers worldwide (Koziell \& Saunders 2001). 
Rural Amazonians have been forced to substantially shift their livelihood strategies as a consequence of dynamic social, economic and political pressures and opportunities. Foremost, the collapse of Brazilian rubber exports saw a diversification of economic portfolios amongst former rubber-tappers (Dean 1987). Subsequently, the creation of extractive reserves, the associated formation of residents' associations, increasing levels of support from management agencies and nongovernment organizations (NGOs), and changing markets for non-timber forest products (NTFPs) have all broadly shaped the evolution of livelihood strategies in Amazonian forest reserves (Hall 2004).

In aggregate, there has been a trend away from traditional extractive exploitation (hereafter extractivism) and towards cattle-ranching and agricultural development in several Amazonian extractive reserves (Ruiz-Perez et al. 2005; Salisbury \& Schmink 2007; Vadjunec \& Rocheleau 2009). Even in largely forested areas of rural Amazonia, smallscale agriculture usually involves successive rotation between cleared forest plots, thereby resulting in shifting land use, often involving detrimental long-term effects to forest cover. The economic prospects of reserve residents may be enhanced in either the short or long term (Hecht 1993), but ephemeral gains in livelihood quality associated with land conversion are often rapidly followed by collapses in both natural capital and living standards (Rodrigues et al. 2009).

Describing pronounced aggregate shifts in livelihood strategies can fail, however, to identify more subtle differences in the contemporary activity budgets adopted by Amazonian agro-extractivist populations. Divergences in livelihood strategy may also occur at the household or community level (Coomes \& Burt 2001). Understanding the behavioural patterns of rural Amazonians, and the drivers of these patterns, is a critical step towards managing legally-occupied protected areas to meet the long-term interests of both forest conservation and local livelihoods. Various demographic, economic, geographic and historical factors are known to influence resource use decision-making in semi-sedentary horticultural societies in the humid tropics. For example, the availability of land suitable for cultivating perennial food crops in roçados (swidden fields) has shaped the settlement patterns of rural Amazonians (Takasaki et al. 2001; Parry et al. 2010a). Engagement in commercial NTFP extractivism can be determined both by access to local markets (Ruiz-Perez et al. 2004) or by migrant and educational background (Stoian 2005). Access to education, healthcare, welfare subsidies and other forms of livelihood support may drive migration patterns of individuals, families or entire communities (Parry et al. 2010a). Deforestation rates often increase with smallholder wealth (Pacheco 2009).

Studying heterogeneity and dynamism in livelihood patterns is important (Salisbury \& Schmink 2007) because agencies working with extractive reserves would benefit from a detailed understanding of how various factors drive or predict the economic activity patterns with which reserve residents engage (Nepstad et al. 2002). This understanding will indicate (1) whether reserves are likely to continue to serve as effective barriers to deforestation (Nepstad et al. 2006); (2) whether they may counter the broad Amazonian trend of rural depopulation (Parry et al. 2010b); and (3) whether or not management programmes and directives should be applied uniformly across different extractive reserves, ignoring within-reserve heterogeneity (Coomes \& Barham 1997). Targeted implementation of management policy, commercial extractivism initiatives and payments for environmental services (PES) programmes will benefit from awareness of the context in which they are being developed. Research and promotion of extractive activities should thus be undertaken with consideration of the livelihoods affected by them.

Here we quantitatively assess the variation in livelihood strategies and modes of production by residents of two extractive reserves in western Brazilian Amazonia with respect to their engagement with both subsistence and incomegenerating activities. We examine the spatial and temporal heterogeneity in livelihood strategies at the levels of both households and entire communities, and seek to understand the factors driving this variation. If household or community characteristics can explain spatial or temporal variation in livelihood strategies, these characteristics may be used to target the implementation of development programmes and subsidies.

\section{METHODS}

\section{Study site}

The study was conducted within and around two contiguous extractive reserves bisected by the Juruá River, a large whitewater tributary of the Amazon (Solimões) River in the State of Amazonas, Brazil. The federally-managed Médio Juruá Extractive Reserve (hereafter, ResEx Médio Juruá) occupies 253227 ha, whilst the larger state-managed Uacari Sustainable Development Reserve (hereafter, RDS Uacari) is 632949 ha in area (Fig. 1). The study site lies 75-175 $\mathrm{m}$ above sea level, with flat or undulating terrain. A wide band of seasonally flooded (várzea) forests along the main river channel are inundated between January and June, whilst terra firme forests at higher elevation are never flooded. The area has a wet tropical climate; rainfall recorded at the Bauana Ecological Field Station (S $5^{\circ} 26^{\prime} 19.032^{\prime} \mathrm{W} 67^{\circ} 17^{\prime} 11.688^{\prime}$ ) during the study period indicated that $3659 \mathrm{~mm}$ and $4649 \mathrm{~mm}$ of rain fell annually in 2008 and 2009, respectively.

The ResEx Médio Juruá and the RDS Uacari, which were decreed in 1997 and 2005, respectively, are currently inhabited by some 4000 legal residents, living in $c .74$ communities of 1-89 households each. Many communities are located on the main river channel, whilst others are found on the banks of tributaries and oxbow lakes on either side of the Juruá River. Residents of these extractive reserves are variously engaged in agricultural and extractive activities for both subsistence and cash income (SDS [Secretaria do Estado do Meio Ambiente 
Figure 1 Location of communities within and immediately outside, the boundaries of the Uacari Sustainable Development Reserve and the Médio Juruá Extractive Reserve in the state of Amazonas, Brazil. Insets show the location of Amazonas within Brazil (above) and the study area within the full protected area network of Amazonas (below).

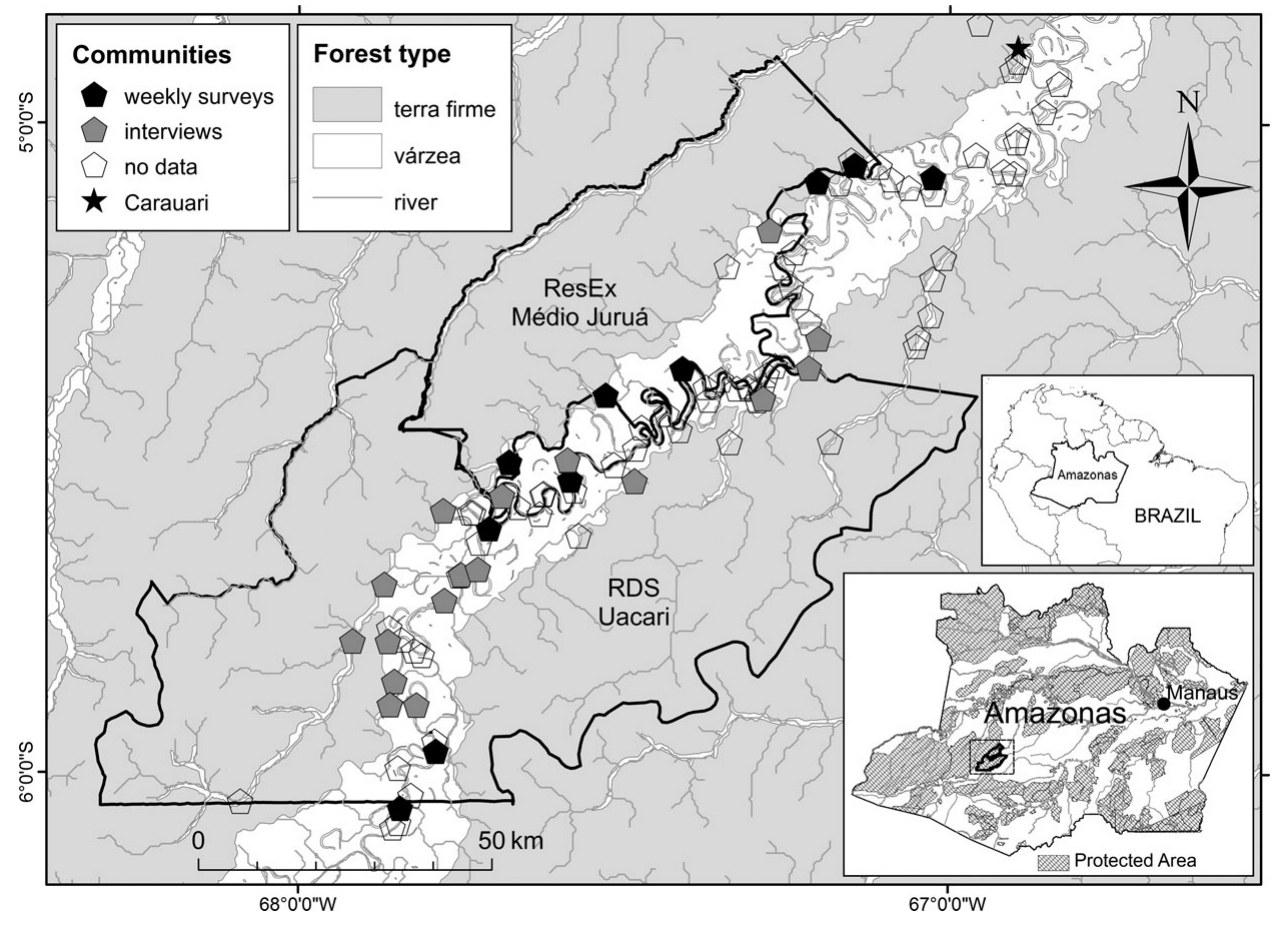

e Desenvolvimento Sustentável] 2010). Both reserves are government-owned but all communities are granted equal, long-term usufruct rights to forest resources.

\section{Data collection}

This research was undertaken as part of a large-scale threeyear research project within this study site, of which all authors were team-members. We collected socioeconomic data from 181 households across eight communities in the ResEx Médio Juruá, 17 communities in the RDS Uacari and two communities immediately adjacent to these two reserves, spanning a c. 320-km section of the Juruá River. The research team maintained a constant physical presence in the reserves throughout, facilitating data collection, reinforcing data quality-control, and enhancing the reliability and level of detail of interviewees' responses.

\section{Weekly household surveys}

Weekly surveys were conducted in 127 households across 14 communities between March 2008 and July 2010. This sampling effort represented $c .21 \%$ of all active households in these two reserves. One resident from each community, who had been previously trained, visited up to 10 randomlyselected households per community on a weekly basis and recorded all extractive and agricultural activities of each household. Each week, this trained resident questioned a senior household member about three categories of activity important for subsistence and cash-income: (1) cultivation of agricultural products; (2) extraction of wild plant forest resources; and (3) fishing. For each activity, the weekly household quantities of all resources collected or produced were recorded, together with their ultimate use (consumed locally or sold), values and markets for traded goods. In the interest of comparability, these questionnaires were based on those used in a biological monitoring programme including several protected areas within the State of Amazonas (Ferraz et al. 2008). The time interval of data collection varied between communities, and some weekly data were missing due to absences of monitoring personnel. We therefore analysed data from all households for which data were available for at least 40 weeks spread over at least a single period of 365 consecutive days, resulting in a subset of 82 households from 10 communities (mean \pm SD number of weekly samples per household $=66.6 \pm 10.3$ ). Another 45 households sampled failed to capture a full year-round seasonality cycle, and were therefore excluded from the analyses.

\section{One-off household and community interviews}

Two modes of one-off interviews were conducted by Peter Newton and Whaldener Endo within 181 households belonging to 27 communities between June and December 2009. These interviews generated predictor variables that were used to model livelihood strategies, and offered an opportunity to gather data to further explain the patterns observed. Firstly, household interviews were undertaken with one or more senior members of each household to document the household's demographic profile, material assets and wealth. Interviewed households were also asked to indicate their highest-earning main activity type as the principal incomegenerating activity. Secondly, community interviews were 
conducted with a senior member of each community (usually the locally elected leader) to document the community's overall demographic profile, physical geographic setting, infrastructure and material assets. Both forms of interview were structured, though additional information was recorded on an ad-hoc basis if offered. We distinguished weekly surveys ( 82 households in 10 communities) from one-off interviews (181 households in 27 communities) throughout the study. All communities and households surveyed weekly were also interviewed.

\section{Data analysis}

\section{Data cleaning}

Weekly survey data occasionally lacked certain details (for example prices in $R \$$; $R \$ 1=$ US\$ 0.60, March 2011) for some resources, so whenever necessary we used productspecific prices, averaged from all other households, to fill these gaps because product prices were temporally and spatially stable, and to allocate zero to all missing values would have unnecessarily biased the data.

Since fish catches were presumed to greatly exceed agricultural and forest extraction events in frequency, surveyed households were only asked details about the previous two days in terms of fishing yields, and the total weekly income derived from fishing. Where necessary, we multiplied the recorded data based on these two days by 3.5 to estimate weekly offtake.

Resources were grouped according to taxonomy and end-use functionality. Agricultural products were generally divided by species. Extractive resources were divided by species where the taxonomy dictated the use and/or price (for example seeds of andiroba trees [Carapa guianensis (Meliaceae)] were specifically used for oil extraction), but were grouped by the extracted plant-part when collectors were less taxonomically discriminatory (e.g. many tree species were collected for firewood, or for their bark). Catches of most fish were reported at the level of species but these were grouped by family using the classification system described by Santos et al. (2006).

Since each resource was recorded using different traditional units of quantity, we hereafter define the number of yield 'events' as the frequency with which each resource was recorded as being produced or extracted, irrespectively of the amount produced or harvested.

All reported correlations use the Pearson coefficient ( $r$ ) as a measure of the strength of association between variables .

\section{Models}

We used multi-level generalized linear mixed models to relate variation in household production and extraction of key resources derived from alternative activity categories to demographic and geographic variables at the household and community level. Multi-model inference based on the AIC information criterion was used to rank the importance of variables and produce model-averaged parameter estimates
(Burnham \& Anderson 2002). We built models using the package 'Ime4' in R ( $\mathrm{R}$ Development Core Team 2010), and used the package 'glmulti' to facilitate multi-model inference based on every possible first-order combination of predictor variables (Calcagno 2010). This package also calculated selection probabilities for each variable, from which we could infer their relative importance. We incorporated a null predictor into the model, with which to identify those predictors with a genuine effect on household production (Boughey et al. 2011).

Mean weekly production rates were calculated separately for each household for the most frequently-produced or harvested agricultural, extractive and fishing resources. Key household and community-level variables were identified and incorporated as predictors, with households nested within a community, which was included as a random variable.

Household-level variables were: family size (total number of people in the household membership); residence period (the number of years the family had been in residence in its current community); welfare income (the mean weekly payment received by the household in the form of government and non-government support grants); and labour income (the mean weekly household income derived from casual labour and state employment).

Community-level variables were: community size (the number of households within any given community); community age (the number of years the community had occupied that location); forest type (measured as the proportion of all land $\left[78.5 \mathrm{~km}^{2}\right]$ within a $5-\mathrm{km}$ radius from the community centre comprised of várzea forest rather than terra firme forest or a permanent water-body); and distance to town (the low-water fluvial distance $[\mathrm{km}]$ from the community to the municipal urban centre, Carauari; Fig. 1). The landscape metric describing the forest type was generated in ArcGIS 9.3 using a 5-km buffer zone around each community, overlain onto a shapefile of vegetation types obtained from the Projeto RADAMBRASIL (1977) survey. This may be the best available proxy for distinguishing forest types within the RDS Uacari, compared to shuttle radar topography mission (SRTM) digital elevation data or alternative vegetation classifications (SDS 2010). Since forest type was measured as the proportion of várzea forest, it follows that a negative model coefficient for this variable indicates that an increased availability of terra firme forest (negatively correlated with várzea forest) has a positive influence on the modelled variable. The network analyst extension of ArcGIS was used to generate the distance to town variable, based on the WWF (World Wildlife Fund) hydrosheds river network data (Lehner et al. 2006). The buffer distance was set at $5-\mathrm{km}$ for both forest type and population density (see below). Although linear distances can only be a proxy for tropical forest accessibility, which is heavily influenced by navigable watercourses and existing forest trails, survey data and local information suggested that a $5-\mathrm{km}$ radius was an approximate mean boundary threshold of resource extraction. 


\section{RESULTS}

\section{Weekly surveys of livelihood activities}

The large number of cultivated and harvested products reported over the entire study were grouped based on congruence of their local names and their end-use functionality, including 21 agricultural products, 20 timber and non-timber forest extractive resources and 17 clades (families) of fish.

Many households also gained income from other sources, including employment by the state (as health agents, school boat drivers, research assistants and in schools; 52 households); employment by neighbours (usually as chainsaw operators or other manual work; 21 households); and from state benefits including Bolsa Familia (a family welfare allowance from the federal government; 132 households), Bolsa Floresta (a payment for environmental services from an NGO; 70 households), and state pensions for elderly or disabled people ( 25 households).

\section{Frequency of resource yield}

A total of 17121 yield events were recorded across the 82 focal households. The frequency of events for the three most frequently-recorded resources in each activity category considered individually was strongly correlated with the quantity produced or extracted $(\mathrm{r}>0.5, p<0.001)$. The number of yield events was therefore a good proxy indicator for comparing the extent of production and extraction of different resources whose quantities were unavoidably measured using different currencies.

Each activity type was dominated by the frequent production or extraction of a small number of key resource commodities. Agricultural activity was focused primarily on the production of farinha (dry manioc flour) from the tubers of Manihot esculenta, a staple carbohydrate that accounted for $63 \%$ of all agricultural yield events (Table 1). A total of only eight products, including manioc flour and a number of fruits, collectively accounted for $95 \%$ of all events with a further 12 infrequently-recorded products jointly summing to $5 \%$. Similarly, forest extractivism was dominated by the collection of firewood ( $40 \%$ of all events), although açai (fruit of the slender palm Euterpe spp.) and rubber (latex of Hevea spp.) were also frequently extracted (21\% and $10 \%$ of events, respectively). Eleven resources accounted for $95 \%$ of events and a further nine accounted for the remaining $5 \%$ (Table 1). Seventeen families of fish were recorded in the catches of the study households, the most frequent family of which (Characidae: for example Pygocentrus spp., Colossoma spp., Brycon spp.) included piranhas, tambaquis and pacus, accounting for $44 \%$ of all catches. Catfishes (Pimelodidae) and cichlids (Cichlidae) were the second and third highest ranking amongst the eight fish families that accounted for $95 \%$ of all fishing events (Table 1).

\section{Local consumption versus sales}

For each of the three activity types, consumption accounted for most yield events, indicating that commercial trade was of secondary importance to subsistence in the livelihood strategies of these rural Amazonians (Table 1). However, the relative extent of consumption and sale varied both between activity categories and resource types.

Only $12 \%$ of all 8805 recorded fish catches were sold, compared to the $20 \%$ of 3969 extracted forest resources. However, the proportion of agricultural products that were sold was much higher $(42 \%)$, indicating that a greater proportion of cash income is derived from plant cultivars rather than from harvesting of wild resources. This trend was mirrored by the mean quantity of resources traded for cash, with fish, forest products and agricultural resources respectively accounting for $8 \%, 37 \%$ and $55 \%$ of all resource units (17 121) recorded (Table 1).

All agricultural products, extractive resources and fish species were consumed locally by a minimum of one household at least once. However, many resources were consumed locally but never sold, and the ratio of local consumption to sales was highly variable. Resources predominantly ( $\geq 80 \%$ ) produced or exploited for commercial purposes included cultivated fruits (bananas, limes and papayas), rubber (Hevea spp. latex) and oilseeds (Carapa guianensis and Astrocaryum murumuru), rather than fish. Conversely, a number of resources were primarily consumed locally, including two agricultural (watermelons and yams), five extractive (firewood, construction timber, the bark of various tree species, and fruits from tucumã palms [Astrocaryum tucuma] and other tree species), and six of the eight top-ranking fish families (Table 1).

\section{Spatial variance in livelihood strategies}

Quantifying livelihood strategies based on self-reporting by households and communities, local consumption was more prevalent than trade. Of 180 respondent households across 27 communities, all reported engaging in agricultural, forest extractivism and fishing activities for subsistence. However, only a fraction of these households and communities reported sales of these major resource types: 144 households in 27 communities sold agricultural products; 141 households in 24 communities sold timber and non-timber resources; and 98 households in 22 communities sold fish.

The ten focal communities within which we obtained detailed weekly survey data shared similar activity profiles in terms of the production and harvesting of resources for subsistence, but varied widely in the extent to which they generated income from these activities. There was little variation across communities in the relative partitioning of engagement between agricultural, extractive and fishing activities for consumption, as indicated both by the overall frequency of events in each category (Fig. 2) and by the monetary value accrued from each activity type (Fig. 2). In 
Table 1 The principal agricultural, forest and fish resources produced and extracted by households in the Médio Juruá region of Amazonas. Within each activity category, the resources that jointly accounted for $95 \%$ of all yield events are listed together with the proportion (Prop.) of all events accounted for by that resource and the volumetric proportion that was consumed locally or sold. The total number of events and total quantity pertaining to each resource are summarized in the final columns. Rows labelled 'Total' show the sum proportion of events and the mean proportion of the quantity consumed locally or sold. *Resources for which $\geq 80 \%$ of yield volume was either consumed or sold. Fishing events are shown from only two surveyed days per week, on the basis of weekly household-scale surveys. inds $=$ individuals, $\mathrm{n} / \mathrm{a}=$ not applicable.

\begin{tabular}{|c|c|c|c|c|c|c|c|c|c|}
\hline \multirow{2}{*}{$\begin{array}{l}\text { Activity } \\
\text { category }\end{array}$} & \multirow{2}{*}{$\begin{array}{l}\text { Product (local } \\
\text { name) }\end{array}$} & \multirow{2}{*}{$\begin{array}{l}\text { Species, genus or } \\
\text { family }\end{array}$} & \multicolumn{2}{|c|}{ Locally consumed } & \multicolumn{2}{|c|}{ Sold } & \multicolumn{3}{|c|}{ Total } \\
\hline & & & $\begin{array}{l}\text { Prop. } \\
\text { events }\end{array}$ & $\begin{array}{l}\text { Prop. } \\
\text { quantity }\end{array}$ & $\begin{array}{l}\text { Prop. } \\
\text { events }\end{array}$ & $\begin{array}{l}\text { Prop. } \\
\text { quantity }\end{array}$ & $\begin{array}{l}\text { No. } \\
\text { events }\end{array}$ & Quantity & Units \\
\hline \multirow[t]{10}{*}{ Agriculture } & Manioc & Manihot esculenta & 0.36 & 0.31 & 0.27 & 0.69 & 2734 & 5164 & 50-kg sacks \\
\hline & Banana & Musa spp. & 0.08 & 0.20 & 0.06 & $* 0.80$ & 631 & 3931 & bunches \\
\hline & Lime & Citrus aurantifolia & 0.00 & 0.01 & 0.04 & $* 0.99$ & 186 & 55978 & inds \\
\hline & Watermelon & Citrullus lanatus & 0.03 & $* 0.89$ & 0.00 & 0.11 & 147 & 4197 & inds \\
\hline & Papaya & Carica papaya & 0.01 & 0.03 & 0.03 & $* 0.97$ & 146 & 3969 & inds \\
\hline & Palm fruit (pupunha) & Bactris gasipaes & 0.02 & 0.52 & 0.01 & 0.48 & 134 & 671 & bunches \\
\hline & Yam & Dioscorea spp. & 0.02 & $* 0.90$ & 0.00 & 0.10 & 75 & 1238 & $\mathrm{kgs}$ \\
\hline & Avocado & Persea americana & 0.01 & 0.77 & 0.00 & 0.23 & 65 & 2202 & inds \\
\hline & 12 other resources & Various species & 0.04 & $\mathrm{n} / \mathrm{a}$ & 0.01 & $\mathrm{n} / \mathrm{a}$ & 229 & $\mathrm{n} / \mathrm{a}$ & $\mathrm{n} / \mathrm{a}$ \\
\hline & & Total & 0.58 & 0.45 & 0.42 & 0.55 & 4347 & & \\
\hline \multirow{13}{*}{$\begin{array}{l}\text { Forest } \\
\text { extractivism }\end{array}$} & Firewood & Various species & 0.40 & $* 1.00$ & 0.00 & 0.00 & 1584 & 1635 & branches \\
\hline & Palm fruit (açaî) & Euterpe spp. & 0.19 & 0.72 & 0.02 & 0.28 & 820 & 3460 & 18-litre tins \\
\hline & Rubber & Heavea spp. & 0.02 & 0.20 & 0.08 & $* 0.80$ & 407 & 7783 & litres \\
\hline & Palm fruit (tucumã) & $\begin{array}{r}\text { Astrocaryum } \\
\text { aculeatum }\end{array}$ & 0.05 & $* 0.99$ & 0.00 & 0.01 & 215 & 6064 & inds \\
\hline & Honey & $\begin{array}{l}\text { Various bee } \\
\text { species }\end{array}$ & 0.01 & 0.26 & 0.04 & 0.74 & 196 & 588 & litres \\
\hline & Seeds (andiroba) & Carapa guianensis & 0.01 & 0.18 & 0.03 & $* 0.82$ & 160 & 1966 & 18-litre tins \\
\hline & Seeds (murumuru) & $\begin{array}{r}\text { Astrocaryum } \\
\text { murumuru }\end{array}$ & 0.00 & 0.06 & 0.02 & $* 0.94$ & 109 & 1288 & 18-litre tins \\
\hline & Fruit: other & Various species & 0.03 & $* 0.95$ & 0.00 & 0.05 & 103 & 2836 & inds \\
\hline & Timber: other & Various species & 0.01 & 0.77 & 0.00 & 0.23 & 73 & 491 & trees \\
\hline & $\begin{array}{l}\text { Timber: } \\
\text { construction }\end{array}$ & Various species & 0.02 & $* 0.99$ & 0.00 & 0.01 & 62 & 91 & metres \\
\hline & Bark & Various species & 0.01 & $* 0.86$ & 0.00 & 0.14 & 58 & 343 & metres \\
\hline & 9 other resources & Various species & 0.04 & $\mathrm{n} / \mathrm{a}$ & 0.01 & $\mathrm{n} / \mathrm{a}$ & 182 & $\mathrm{n} / \mathrm{a}$ & $\mathrm{n} / \mathrm{a}$ \\
\hline & & Total & 0.80 & 0.63 & 0.20 & 0.37 & 3969 & & \\
\hline \multirow[t]{10}{*}{ Fishing } & $\begin{array}{l}\text { Tambaquí, pacu, } \\
\text { piranha etc. }\end{array}$ & Characidae & 0.41 & $* 0.96$ & 0.03 & 0.04 & 3936 & 64558 & inds \\
\hline & $\begin{array}{l}\text { Surubim, mandim, } \\
\text { pirarara etc. }\end{array}$ & Pimelodidae & 0.12 & 0.68 & 0.07 & 0.32 & 1710 & 10362 & inds \\
\hline & $\begin{array}{l}\text { Tucunaré, carauaçú } \\
\text { etc. }\end{array}$ & Cichlidae & 0.08 & $* 0.98$ & 0.00 & 0.02 & 674 & 4309 & inds \\
\hline & Jaraquí, curimatã & Prochilodontidae & 0.07 & $* 1.00$ & 0.00 & 0.00 & 605 & 4594 & inds \\
\hline & Piau & Anostomidae & 0.07 & $* 0.97$ & 0.00 & 0.03 & 598 & 6147 & inds \\
\hline & Aruanã, piraracu & Osteoglossidae & 0.05 & 0.75 & 0.01 & 0.25 & 507 & 1853 & inds \\
\hline & Bodó & Loricariidae & 0.03 & $* 1.00$ & 0.00 & 0.00 & 270 & 4587 & inds \\
\hline & Cascuda, branquinha & Curimatidae & 0.01 & $* 1.00$ & 0.00 & 0.00 & 125 & 4231 & inds \\
\hline & 9 other families & Various species & 0.04 & $\mathrm{n} / \mathrm{a}$ & 0.00 & $\mathrm{n} / \mathrm{a}$ & 380 & $\mathrm{n} / \mathrm{a}$ & $\mathrm{n} / \mathrm{a}$ \\
\hline & & Total & 0.88 & 0.92 & 0.12 & 0.08 & 8805 & & \\
\hline
\end{tabular}

contrast, there was a large degree of heterogeneity in the frequency of activities for income-generation (Fig. 2) and the proportion of community-level income derived from each activity type (Fig. 2).

Engagement with alternative income-generating activities showed a high degree of congruence between households belonging to the same community. All of the 82 weeklysurveyed households gained over half of their total annual income from a single activity type (mean \pm SD proportion of total income from this activity $=0.85 \pm 0.14$ ) and so self-assessed ranking of activity importance proved to be a good proxy for community activity profiles (strong 
Figure 2 Variation in livelihood strategies by rural Amazonians in the Médio Juruá region of Amazonas. On the basis of weekly household surveys: the relative frequency with which communities engaged in agrarian, extractive and fishing activities for $(a)$ sale and $(b)$ local consumption; the relative monetary value of resources produced or extracted for $(c)$ sales and $(d)$ local consumption. On the basis of one-off interviews: the relative frequency with which each activity was ranked as the principal income-generating activity by households within communities $(e)$ surveyed on a weekly basis and $(f)$ for which no comparable weekly survey data are available. The number of households surveyed and interviewed in each

community are indicated at the top of the bars $(e, f)$. In $(a)$ and $(b)$, fishing events are shown from only the two surveyed days per week.

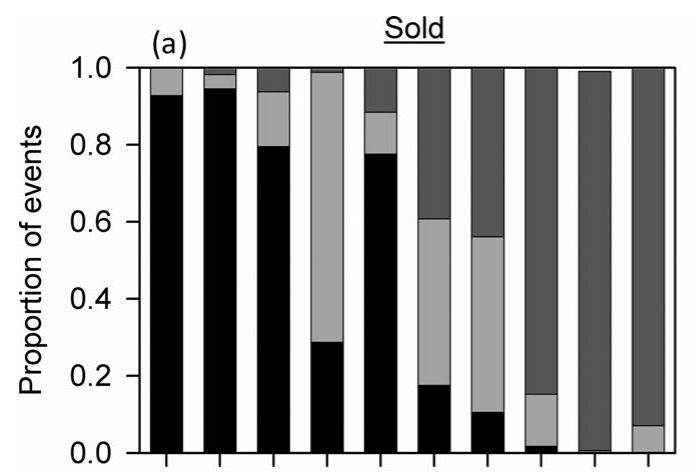

(b)

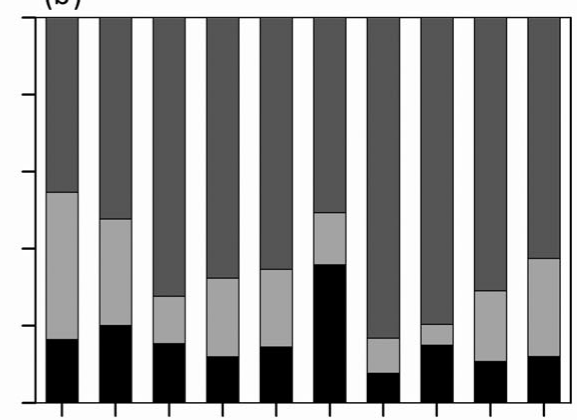

(c)

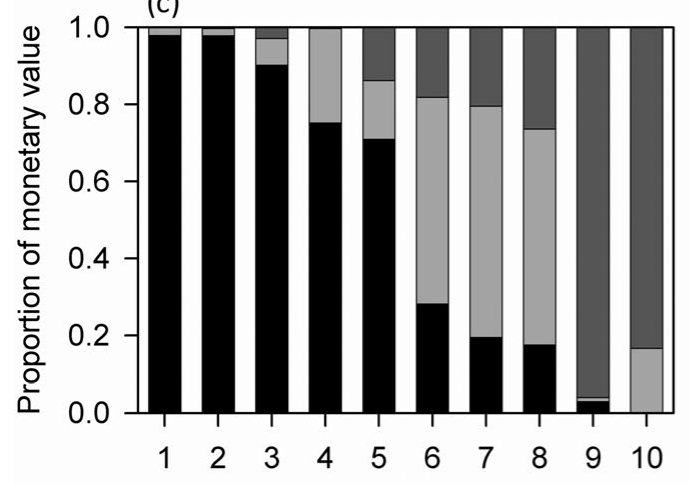

(d)

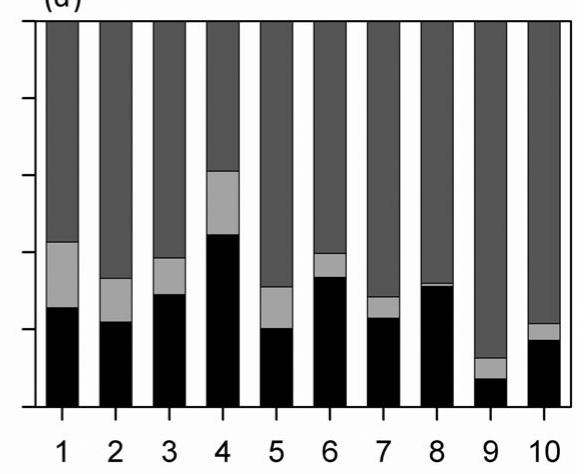

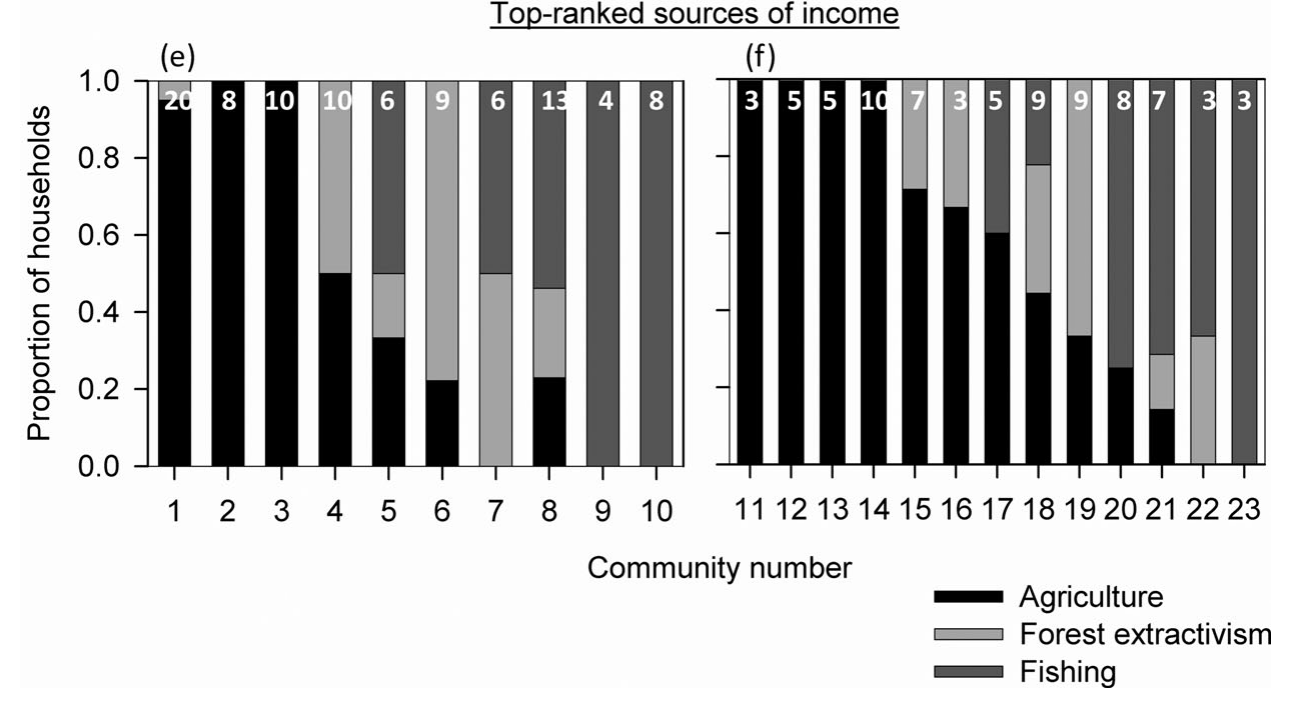

congruence between Fig. $2 c$ and $e$ ). In 65 of 82 cases, the highest-ranked activity from weekly survey data matched that of the household's own assessment. The rankings reported by communities that were not surveyed on a weekly basis (Fig. 2) can therefore be interpreted as a fair approximation of community livelihood strategies on a wider spatial scale.

Households within a community were much more likely to converge in their principal income-generating activity than would be expected by chance (Fig. 2), indicating that household activity profiles are reflected at the communitywide level. Only three communities contained at least one household engaged primarily in each of the three activities. In

nine out of 27 communities, all households ranked the same activity as being their most important income-generator and households in the other 15 communities reported just two of the three activities as their principal income source.

\section{Temporal variation in resource use}

The heaviest rainfall in the Juruá region was in NovemberApril but water levels lagged this by $c$. 14 weeks (Fig. 3). The várzea forest was therefore usually accessible on foot for the second half of each year, but was inundated by up to $c .11 \mathrm{~m}$ of water between January and June. 

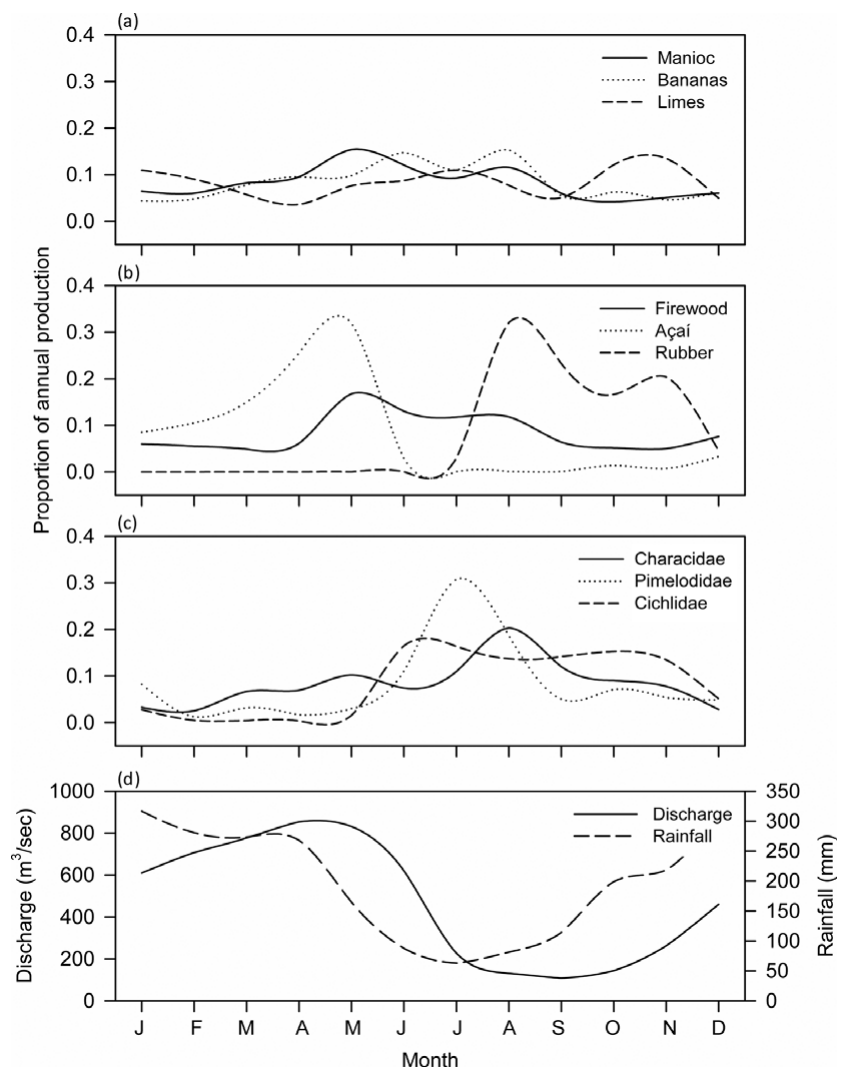

Figure 3 Temporal variation in the yield rates of the three main resource types produced or extracted in the study reserves, as measured by the monthly proportion of $(a)$ agricultural, $(b)$ extractive and $(c)$ fish yields in relation to annual totals. Principal resources illustrated in each case are those that accounted for the greatest number of events in each activity category (see Table 1). The monthly variation $(d)$ in mean rainfall is as measured at the Eirunepé meteorological station (2000-2010) and mean discharge $\left(\mathrm{m}^{3} \mathrm{~s}^{-1}\right)$ is of the Juruá River measured at Porto Gavião, Carauari (1972-1994) (Source: Petrobras).

Weekly surveys of resource use indicated significant variation in the relative consistency of monthly offtakes of the main resources in each of the three activity categories. The principal agrarian and fish resources were less variable over time than extractive plant products, with greater monthly variation in the proportion of the total annual harvest derived from the three most frequently-extracted plant resources than from the other two activity types (for example variance in monthly offtake of manioc $=0.001$, rubber $=0.013$, açaí $=$ 0.012 ; Fig. 3). Firewood, the most frequently extracted class of plant products, was collected throughout the year, but açaí fruits were only available during the mid-wet to early-dry season (January-June), and rubber was tapped only between July and December. The proportion of the total harvest of the three most important fish families peaked during the dry season (May-August), though these were caught throughout the year.

\section{Determinants of production and extraction of key resources}

We have shown that livelihood strategies of reserve residents were dedicated to relatively few key resources, despite the overall high diversity of resources produced or extracted. The best single models for the production and extraction of these four resources had only intermediate or low Akaike weights (manioc: $\omega_{i}=0.74$, firewood: $\omega_{i}=0.69$, açaí: $\omega_{i}=0.41$; characid fish: $\omega_{i}=0.51$ ) suggesting uncertainty in relation to alternative models, thereby supporting the use of a model-averaging approach (Table 2). Production of manioc and extraction of all other resources were explained by three to five alternative models forming the $95 \%$ set of models (summed $\omega_{i} \geq 0.95$ ).

The best model for manioc production and firewood and characid fish extraction included the variable forest type, which appeared in at least half of all models in the 95\% set for all these resources. Negative relationships between this variable and manioc production and firewood extraction indicate the importance of terra firme forest in predicting offtake of these resources, whilst a positive relationship with characid fish extraction suggests that larger spatial extents of várzea forest were associated with greater offtake of aquatic resources. The high sum of Akaike weights for the variable forest type for all three resources (Table 2) corroborates its importance for any model. The landscape structure in the general neighbourhood of settlements was therefore clearly a good indicator of relative effort allocated to agricultural, fishing and other extractive activities. However, while the Akaike weight for forest type in the model set for açaí extraction was moderately high $\left(\omega_{i}=0.27\right)$, this compared unfavourably with the null predictor (upper $95 \%$ percentile $\omega_{i}=0.36$ ), casting doubt on the importance of local forest composition for açaí harvest levels.

Family size was also included within all of the model sets, but only within the model set for açaí extraction did the sum of Akaike weights $\left(\omega_{i}=0.57\right)$ compare favourably against the null predictor. Higher labour input from larger families resulted in greater weekly volumes of these palm fruits.

\section{Forest type}

Forest type was used as a proxy for relative accessibility of different forest habitats by community members. The variable was a strong predictor of household offtake in three of the four top-ranking model sets. Mean household production of manioc and collection of firewood were negatively correlated with the extent of flooded forests within a $5-\mathrm{km}$ radius of the community, whereas communities largely surrounded by flooded forest exhibited higher yields of characid fish.

An alternative measure of manioc production, namely the number of $50-\mathrm{kg}$ sacks of manioc flour produced by households surveyed each week, was highly correlated with the number of manioc stems that those households reported to have planted most recently in swidden fields $(r=0.847$, 
Table 2 Summary of multi-level mixed effects models of mean weekly production or extraction of manioc flour, firewood, açaí fruit and characid fish by households in the Médio Juruá region of the Brazilian state of Amazonas. All models that make up $95 \%$ of the sum Akaike weight $\left(\omega_{i}\right)$ are shown. $*$ Variables included in each model. Model averaged Akaike weights for each variable are indicated above the first model of each set. In the logarithmic notation used for $\beta$ and variance, $1.58 \mathrm{E}-01$ indicates $1.58 \times 10^{-1}$.

\begin{tabular}{|c|c|c|c|c|c|c|c|c|c|c|c|c|c|c|c|}
\hline \multirow[t]{2}{*}{ Resource } & \multirow{2}{*}{$\begin{array}{l}\text { No. models } \\
\text { in } 95 \% \text { set }\end{array}$} & \multirow[t]{2}{*}{ Model } & \multirow[t]{2}{*}{ Intercept } & \multicolumn{4}{|c|}{ Household covariates } & \multicolumn{4}{|c|}{ Community covariates } & \multirow{2}{*}{$\begin{array}{c}\text { Null } \\
\text { predictor }\end{array}$} & \multirow[t]{2}{*}{$I C$} & \multirow[t]{2}{*}{$\Delta I C$} & \multirow[t]{2}{*}{$\omega_{i}$} \\
\hline & & & & $\begin{array}{c}\text { Family } \\
\text { size }\end{array}$ & $\begin{array}{l}\text { Residence } \\
\text { period }\end{array}$ & $\begin{array}{l}\text { Welfare } \\
\text { income }\end{array}$ & $\begin{array}{l}\text { Labour } \\
\text { income }\end{array}$ & $\begin{array}{c}\text { Community } \\
\text { size }\end{array}$ & $\begin{array}{c}\text { Community } \\
\text { age }\end{array}$ & Forest type & $\begin{array}{c}\text { Distance } \\
\text { to town }\end{array}$ & & & & \\
\hline \multirow{6}{*}{$\begin{array}{l}\text { Log no. } \\
\text { sacks of } \\
\text { manioc } \\
\text { flour per } \\
\text { week }\end{array}$} & \multirow{6}{*}{3} & & 1.00 & 0.21 & 0.00 & 0.00 & 0.00 & 0.01 & 0.00 & 0.94 & 0.00 & 0.37 & & & \\
\hline & & 1 & $*$ & & & & & & & $*$ & & & 48.22 & 0.00 & 0.74 \\
\hline & & 2 & * & * & & & & & & $*$ & & & 50.92 & 2.70 & 0.19 \\
\hline & & 3 & $*$ & & & & & & & & & & 54.27 & 6.06 & 0.04 \\
\hline & & $\beta$ & $1.06 \mathrm{E}+00$ & $3.42 \mathrm{E}-02$ & $-6.86 \mathrm{E}-03$ & $-1.34 \mathrm{E}-03$ & $8.60 \mathrm{E}-04$ & $1.10 \mathrm{E}-01$ & $-3.75 \mathrm{E}-01$ & $-2.60 \mathrm{E}-01$ & $-1.43 \mathrm{E}-01$ & & & & \\
\hline & & variance & $1.58 \mathrm{E}-01$ & 4.57E-08 & $1.73 \mathrm{E}-06$ & $1.48 \mathrm{E}-11$ & $5.82 \mathrm{E}-13$ & $5.06 \mathrm{E}-04$ & 7.61E-02 & $3.72 \mathrm{E}-02$ & $1.24 \mathrm{E}-02$ & & & & \\
\hline \multirow{7}{*}{$\begin{array}{l}\text { Log no. } \\
\text { branches } \\
\text { of firewood } \\
\text { per week }\end{array}$} & \multirow[t]{7}{*}{5} & 1 & $\begin{array}{l}1.00 \\
*\end{array}$ & 0.14 & 0.01 & 0.00 & 0.00 & 0.03 & 0.04 & $*^{0.87}$ & 0.01 & 0.67 & 274.10 & 0.00 & 0.69 \\
\hline & & 2 & $*$ & $*$ & & & & & & $*$ & & & 277.80 & 3.70 & 0.11 \\
\hline & & 3 & $*$ & & & & & & & & & & 278.07 & 3.96 & 0.10 \\
\hline & & 4 & $*$ & & & & & & $*$ & $*$ & & & 280.36 & 6.26 & 0.03 \\
\hline & & 5 & $*$ & & & & & $*$ & & $*$ & & & 281.43 & 7.32 & 0.02 \\
\hline & & $\beta$ & $8.12 \mathrm{E}+00$ & $8.73 \mathrm{E}-02$ & $7.56 \mathrm{E}-02$ & $8.62 \mathrm{E}-03$ & $-2.04 \mathrm{E}-02$ & $6.06 \mathrm{E}-02$ & $6.30 \mathrm{E}-01$ & $-4.16 \mathrm{E}+00$ & $4.51 \mathrm{E}-03$ & & & & \\
\hline & & variance & $7.39 \mathrm{E}-01$ & $2.07 \mathrm{E}-07$ & $5.53 \mathrm{E}-05$ & 7.67E-09 & $3.88 \mathrm{E}-07$ & $1.84 \mathrm{E}-03$ & $1.79 \mathrm{E}-01$ & $1.29 \mathrm{E}-01$ & $7.83 \mathrm{E}-10$ & & & & \\
\hline \multirow{7}{*}{$\begin{array}{l}\text { Log no. } \\
\text { 18-litre } \\
\text { tins of açaí } \\
\text { fruit per } \\
\text { week }\end{array}$} & \multirow{7}{*}{4} & & 1.00 & 0.57 & 0.00 & 0.00 & 0.00 & 0.00 & 0.01 & 0.27 & 0.00 & 0.36 & & & \\
\hline & & 1 & $*$ & $*$ & & & & & & & & & 21.15 & 0.00 & 0.41 \\
\hline & & 2 & $*$ & & & & & & & & & & 21.72 & 0.57 & 0.31 \\
\hline & & 3 & $*$ & $*$ & & & & & & $*$ & & & 23.19 & 2.04 & 0.15 \\
\hline & & 4 & $*$ & & & & & & & $*$ & & & 23.69 & 2.54 & 0.12 \\
\hline & & $\beta$ & $2.07 \mathrm{E}-01$ & $3.34 \mathrm{E}-02$ & $5.19 \mathrm{E}-01$ & $-1.60 \mathrm{E}-01$ & $1.26 \mathrm{E}-03$ & $1.74 \mathrm{E}-02$ & $1.47 \mathrm{E}-03$ & $-5.59 \mathrm{E}-02$ & $-1.15 \mathrm{E}-03$ & & & & \\
\hline & & variance & $5.93 \mathrm{E}-03$ & $8.47 \mathrm{E}-08$ & $1.40 \mathrm{E}-01$ & $2.46 \mathrm{E}-03$ & $5.21 \mathrm{E}-12$ & $6.88 \mathrm{E}-06$ & $2.72 \mathrm{E}-10$ & $8.90 \mathrm{E}-05$ & $1.09 \mathrm{E}-12$ & & & & \\
\hline \multirow{6}{*}{$\begin{array}{l}\text { Log no. } \\
\text { characid } \\
\text { fish per } \\
\text { week }\end{array}$} & \multirow{6}{*}{4} & 1 & $\begin{array}{l}1.00 \\
*\end{array}$ & 0.10 & 0.01 & 0.00 & 0.00 & 0.01 & 0.04 & * 0.60 & 0.00 & \multirow[t]{6}{*}{0.48} & 126.99 & 0.00 & 0.51 \\
\hline & & 2 & $*$ & & & & & & & & & & 127.80 & 0.80 & 0.34 \\
\hline & & 3 & $*$ & $*$ & & & & & & * & & & 131.40 & 4.40 & 0.06 \\
\hline & & 4 & $*$ & $*$ & & & & & & & & & 132.26 & 5.27 & 0.04 \\
\hline & & $\beta$ & $1.66 \mathrm{E}+00$ & $2.02 \mathrm{E}-01$ & $2.30 \mathrm{E}-01$ & $-4.82 \mathrm{E}-01$ & $3.75 \mathrm{E}-01$ & $-1.90 \mathrm{E}-03$ & $2.46 \mathrm{E}-01$ & $1.43 \mathrm{E}+00$ & $5.36 \mathrm{E}-02$ & & & & \\
\hline & & variance & $7.74 \mathrm{E}-03$ & $7.17 \mathrm{E}-03$ & $7.56 \mathrm{E}-03$ & $1.68 \mathrm{E}-01$ & $3.65 \mathrm{E}-02$ & 4.84E-09 & $1.45 \mathrm{E}-02$ & $2.44 \mathrm{E}-01$ & $3.26 \mathrm{E}-05$ & & & & \\
\hline
\end{tabular}




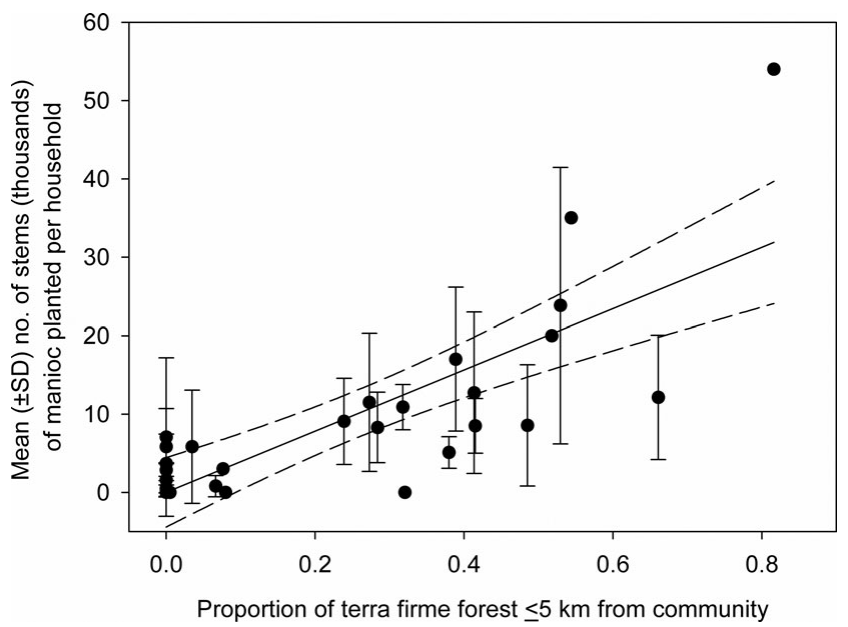

Figure 4 The influence of the availability of terra firme forest within a $5-\mathrm{km}$ radius of communities on manioc production, based on the number of stems planted per household per community (mean $\pm \mathrm{SD}$ ). Solid and dashed lines indicate the overall linear regression and $95 \%$ confidence intervals, respectively.

$n=78, p<0.001)$. This indicates both that interviewees were able to accurately report their current manioc crop size and that there was a strong linear relationship between crop size and agricultural output. We therefore used crop size (the number of planted stems reported by all 181 interviewed households) as a proxy for manioc production, and tested the relationship between crop size and terra firme availability (the proportion of terra firme forest within this 5 -km radius) for all households. Mean crop size per community was strongly correlated with the availability of terra firme $(r=0.782$, $n=27, p<0.001$; Fig. 4), and thus predicted the extent of agrarian effort throughout the two reserves and not just those 10 communities surveyed on a weekly basis.

This dependence on terra firme land for agricultural production is further emphasized by the significant difference in forest landscape structure between nine communities reporting no sales of processed manioc and 17 communities that derived at least some income from manioc sales (proportion of várzea forest for non-trading communities = $0.86 \pm 0.10$; proportion of várzea forest for trading communities $=0.57 \pm 0.21$; t-test: $t=4.639, p<0.001)$. Communities whose operational forest cover contained a high proportion of seasonally flooded forest tended to produce sufficient manioc for subsistence only.

\section{DISCUSSION}

\section{Overview}

Common to all households were the imperatives of manioc cultivation as the staple carbohydrate, fishing as a principal source of protein and the harvest of timber and nontimber forest products for food, fuel and the construction of houses and canoes. However, there was considerable variation between livelihood strategies of individual households within this study system, particularly with respect to the main income-generating activities with which they engaged. We now discuss how understanding the biophysical and demographic factors that influence this variation can be important to reserve managers and agencies wishing to implement development and subsidy programmes designed to modulate the behaviour of rural Amazonians.

\section{Extractive reserves or agricultural enclaves within a forest landscape?}

The extractive reserve concept originally sought to ensure land-tenure rights for traditional communities, though this subsequently broadened to additionally juxtapose biodiversity conservation objectives. Whilst manioc cultivation has traditionally been a means of producing farinha (a staple carbohydrate in Amazonia) for subsistence in rural areas, it was implicit within the extractive reserve philosophy that Amazonians living within these reserves would engage primarily in traditional extractive activities that exploited NTFPs such as rubber, Brazil nuts, copaíba oleoresin and andiroba oil for income-generation (Fearnside 1989). Yet our results suggest that a large proportion of income in some households is derived from agricultural products, often with minimal engagement in commercial extractivism. This finding accords with the temporal shift away from forest extractivism and towards agricultural and ranching activities documented in other Amazonian agro-extractive systems (Ruiz-Perez et al. 2005; Salisbury \& Schmink 2007; Vadjunec \& Rocheleau 2009). Whilst this study focused on only two of 199 extractive reserves currently decreed in Brazilian Amazonia, the Médio Juruá reserves are widely renowned as containing some of the most 'traditional' communities of forest extractivists.

\section{Subsistence and cash economies}

Our figures suggest that the relative frequency and inferred monetary value derived from the three main activity categories was much more similar for subsistence than for commercial trade. We therefore infer that most reserve residents have access to the full complement of resources required to maintain their livelihoods from a subsistence perspective, but that local resource availability largely determines which products are sufficiently abundant to enable surplus offtake to be sold.

\section{Temporal variation}

Most communities with immediate access to unflooded terrain planted small swidden fields of manioc in August, subsequently harvesting and processing the tubers to produce farinha throughout the year. Manioc cultivation thus provides these communities with a consistent source of year-round food and income.

In contrast, many of the most commercially-important NTFPs in this system were highly seasonal in their 
availability. Fruits and seeds, such as açaí fruits and the andiroba oilseeds of Carapa guianensis, are only a viable source of income during their fruiting season, and overall abundance may be subject to large supra-annual variation in fruit crop sizes. Hevea spp. trees may produce rubber all yearround but commercially-exploited congeners are restricted to floodplain forest, which is only accessible on foot between August and December. Some terra firme NTFPs such as lianas and understorey palms are available all year, but these are generally harvested for local consumption (for example construction) only, rather than sale.

\section{Convergence between households within a community}

Our models suggest that shared geographic constraints within the community catchment area represent key factors in the close congruence between household livelihood strategies within a given community. If the viability and profitability of alternative activities is determined by common communitylevel variables such as forest type, distance to markets, fluvial location or communal ownership of large boats, then we would expect to see nested choices of activity engagement amongst neighbours.

Additionally, the distinct social structure of these rural populations is such that communities often consist of one or more extended families bounded by kinship ties. Households within a particular community are thus more genetically related, as well as physically and socially connected. Family traditions, including their cultural or religious preferences and taboos, may therefore also contribute to intra-community congruence in lifestyles.

Regardless of the underlying drivers of the consistent tendency for households within communities to adopt similar livelihood strategies, this has implications for researchers and managers wishing to rapidly gauge the distribution of activity engagement across protected areas. Moreover, the c. $80 \%$ similarity between detailed weekly survey data at the level of households and one-off self-assessments of principal incomegenerating activities at the level of communities suggests that targeted interviews yield good proxy responses to at least some questions about resource-use decision-making.

\section{Agriculture}

Engagement in agriculture was largely explained by the predominant forest type in the vicinity of each community. The number of manioc stems (which scales linearly with swidden field size) currently planted by a household was also a good predictor of agricultural productivity, confirming that the explanatory variable we identified through our models applied over a larger number of communities. Perennial crops like manioc require permanently unflooded land, since tubers typically require 12 months to attain a suitable harvest size. Households with limited access to terra firme land often cultivated manioc gardens within várzea habitat (on seasonally-exposed beaches and floodplains), but harvested them after only six months and before the flood pulse, thereby enabling production of just enough farinha to meet their own subsistence needs. This reliance on swidden fields created in areas of terra firme forest for manioc agriculture has implications for PES programmes such as Bolsa Floresta, which seek to maintain environmental services by restricting further forest clearance (Viana 2008; Newton et al. 2011a).

\section{Forest extractivism}

The most frequently harvested class of forest product, firewood, was unsurprisingly collected throughout the year but this seldom amounted to a destructive means of timber harvesting since dead wood is often collected off the ground, often from cleared swidden fields. The propensity for households in settlements with a relatively high proportion of neighbouring terra firme forest to collect more firewood was largely a result of higher demand; firewood was primarily collected to fuel the large wood-fired ovens required for the farinha-making process, whereas butane gas was the most common fuel for domestic cooking. Changes in agrarian activities may thus directly affect the harvest of this resource.

Commercial dependence on forest extractivism was not homogenous across the reserve communities. Whilst we did not model the extraction of any of the most significant economically-exploited NTFPs (such as andiroba and murumuru seeds, and latex from rubber trees), the widespread occurrence of these resources in flooded forest and their absence from terra firme forest indicates greater engagement in commercial trade of NTFPs by communities with greater access to the former forest type.

These commercially-valuable NTFPs, similarly to manioc but in contrast to most fish, were relatively high-value per unit weight commodities and, critically, were nonperishable and could thus endure the inevitable delay between harvest and sale. These commodities also enjoyed relatively secure purchase quotas and markets, with annuallydetermined buying prices guaranteed by local residents' associations and cooperatives. Indeed, a prioritized goal of government agencies and NGOs involved in rural livelihood development in rural Amazonia has been the promotion of extractive industries as a means of augmenting household incomes (Belcher et al. 2005). In our study reserves, a community-run cooperative extracts andiroba oil from Carapa guianensis seeds, selling the oil wholesale to a large cosmetic company (Natura 2007). Smaller-scale projects have included establishing meliponiculture of native stingless bee hives in some communities, and training and equipping reserve residents to extract Copaifera oleoresin (Newton et al. 2011b). Implementation of these projects has tended to assume a 'onesize-fits-all' approach, whereas our data clearly show that resource accessibility and current livelihood practices are not uniform, and may strongly influence the uptake and success of each of these initiatives. The development of extractive industries therefore demands consideration of the historical, 
socioeconomic and especially the geographic context within which they are being introduced.

Further, the plethora of government subsidies associated with many NTFPs makes an accurate analysis of their true value to household economies very difficult, since many of the more economically-significant NTFPs benefit from both direct and indirect subsidies. A combination of direct government and NGO subsidies, for example, maintains the buying price of rubber at a level at which it remains profitable for reserve residents to continue to extract it. Less directly, the offtake volume of andiroba seeds required by the cooperative is allocated to all participating communities on an equitable quota system. The seeds are then collected from each community by the cooperative's own boat, effectively removing the usual diminishing returns of transport costs incurred by producers living further from markets.

Yet studying extractive systems embroiled in subsidies and welfare payments is worthwhile, since this increasingly represents the way in which extractive reserves are operating. Such an approach may prove to be a sustainable way to overcome the problems of fluctuating markets, diminishing profits with increasing travel distances, and local overexploitation of natural resources that are frequently associated with extractive systems (Belcher \& Schreckenberg 2007).

Finally, not all forms of forest extractivism are equally benign or desirable. Manufacturing canoes, for example, involves the removal of an entire tree and thus may not be as sustainable on the same scale as the collection of oilseeds or oleoresins. Although more assessments of the ecological impacts of NTFP harvesting have become available (see for example Peres et al. 2003; Ticktin 2004; Vadjunec \& Rocheleau 2009), resource- or site-specificity is often high and reserve managers need to consider the likely implications of actively encouraging or subsidising forest extractivism.

\section{Fishing}

Fishing yields depended on access to rivers, lakes and seasonally inundated forest. The last is particularly important at times of year when the main rivers and lakes are less productive and so forest type was again a key predictor of fishing yields. Although commercial fishing was prohibited within many of the reserves' oxbow lakes, this was the principal income-generating activity for some communities. This specialization required cold-storage facilities for maintaining fish catches, and long-term arrangement with commercial fishing boats that would periodically bulk-buy captured stock. For the majority of communities, travel time to urban markets precluded frequent sale of perishable fish catches.

\section{Drivers of variation}

Few of the demographic variables examined here were significant predictors of household resource offtake. However, communities enjoying greater access to terra firme forest tended to be larger, with implications for longer-term planning of reserve settlements. Communities are often transient and frequently relocate, particularly with respect to meandering river channels in highly dynamic fluvial systems like the Juruá (Abizaid 2005).

Forest landscape composition captured the physical geography of the area around settlements. Measured as relative proportions of terra firme and várzea forest, this variable was consistently the strongest predictor of mean weekly household offtake of key agrarian and extractive resources. Although the size of communities' catchment areas, from within which most of their resources are harvested, is likely to be a function of numerous factors including transport infrastructure, resource demand, and local spatial configuration of fluvial and forest systems, the partition of neighbouring forest into terra firme and várzea forest is clearly an important influence on the relative use of different resource types. Therefore whilst other factors may affect aggregate resource-use decisions on a wider spatial scale, we suggest that local variation in livelihood strategy may largely be determined by the distribution of forest types in reserves and landscapes elsewhere.

\section{CONCLUSIONS}

Understanding spatial and temporal patterns of resource use and availability within multiple-use tropical forest reserves is critical in helping managers to effect change within dynamic demographic and economic scenarios. Our data add to the body of evidence suggesting that, in terms of local patterns of subsistence and income, agriculture may be equally, if not more, important than extractivism of fish and forest products in many Amazonian reserves (see Salisbury \& Schmink 2007). However, we additionally demonstrate that the significant temporal and spatial variation in the livelihood strategies employed by rural Amazonians living in communities within these reserves may be largely driven by local geography and consequent resource accessibility. This finding complements those from similar agro-extractivist systems, where livelihood strategy is dictated by land tenure (see Takasaki et al. 2001). Given the wide heterogeneity in economic profiles even within the same geographic area, we suggest that careful consideration should be paid to the non-uniform impacts that the implementation of development programmes (such as the promotion of new extractive activities), the enforcement of reserve regulations from reserve management plans, and the introduction of PES and welfare subsidies may have within multiple-use protected areas.

\section{ACKNOWLEDGEMENTS}

This study was funded by a NERC studentship (3410625) to Peter Newton and a DEFRA Darwin Initiative (UK) grant (ref. 16-001) to Carlos A. Peres. We wish to thank the Secretaria do Estado do Meio Ambiente e Desenvolvimento Sustentável (SDS) of Amazonas and the Instituto Brasileiro do Meio Ambiente e Recursos Naturais Renováveis (IBAMA) 
for supporting this research. Weekly survey data-collection forms were adapted from those used by the Programa de Monitoramento da Biodiversidade e do Uso de Recursos Naturais em Unidades de Conservação Estaduais do Amazonas (ProBUC). We are indebted to the household monitors for their diligent work conducting weekly surveys. We thank J. Hawes and two anonymous reviewers for comments on an earlier draft. This is publication no. 3 of the Prójeto Médio Juruá series on resource management in Amazonian reserves (see http://www.tropicalforestresearch.org/projects/jurua.aspx).

\section{References}

Abizaid, C. (2005) An antropogenic meander cutoff along the Ucayali River, Peruvian Amazon. American Geographical Reviem 95: 122 135.

Allegretti, M.H. (1990) Extractive reserves: an alternative for reconciling development and environmental conservation in Amazonia. In: Alternatives to Deforestation: Steps Tomard Sustainable Use of the Amazonian Rain forest, ed. A. B. Anderson, pp. 252-264 New York, NY, USA: Columbia University Press.

ARPA (2010) Programa Àreas Protegidas da Amazônia: Amazônia Brasileira. Instituto Socioambiental, Manaus, Brazil.

Belcher, B. \& Schreckenberg, K. (2007) Commercialisation of nontimber forest products: a reality check. Development Policy Reviem 25: 355-377.

Belcher, B., Ruiz-Perez, M. \& Achdiawan, R. (2005) Global patterns and trends in the use and management of commercial NTFPs: implications for livelihoods and conservation. World Development 33: $1435-1452$.

Boughey, K.L., Lake, I.R., Haysom, K.A. \& Dolman, P.M. (2011) Effects of landscape-scale broadleaved woodland configuration and extent on roost location for six bat species across the UK. Biological Conservation doi: 10.1016/j.biocon.2011.06.008.

Burnham, K.P. \& Anderson, D.R. (2002) Model Selection and Multimodel Inference: a Practical Information-theoretic Approach. New York, NY, USA: Springer.

Calcagno, V. (2010) glmulti: GLM model selection and multimodel inference made easy. $\mathrm{R}$ package version $0.6-3$ [www document]. URL http://CRAN.R-project.org/package=glmulti

Campos, M.T. \& Nepstad, D.C. (2006) Smallholders, the Amazon's new conservationists. Conservation Biology 20: 1553-1556.

Coomes, O.T. \& Barham, B.L. (1997) Rain forest extraction and conservation in Amazonia. The Geographical fournal 163: 180 188.

Coomes, O.T. \& Burt, G.J. (2001) Peasant charcoal production in the Peruvian Amazon: rainforest use and economic resiliance. Forest Ecology and Management 140: 39-50.

Dean, W. (1987) Brazil and the Struggle for Rubber. Cambridge, UK: Cambridge University Press.

Fearnside, P.M. (1989) Extractive reserves in Brazilian Amazonia. Bioscience 39: 387-393.

Ferraz, G., Marinelli, C.E. \& Lovejoy, T.E. (2008) Biological monitoring in the Amazon: recent progress and future needs. Biotropica 40: 7-10.

Hall, A. (2004) Extractive reserves: building natural assets in the Brazilian Amazon. Working Paper Series, Political Economy Research Institute, University of Massachusetts, Amherst, MA, USA.
Hecht, S.B. (1993) The logic of livestock and deforestation in Amazonia. Bioscience 43: 687-695.

Koziell, I. \& Saunders, J. (2001) Living off Biodiversity: Exploring Livelihoods and Biodiversity Issues in Natural Resources Management. London, UK: International Institute for Environment and Development (IIED).

Lehner, B., Verdin, K. \& Jarvis, A. (2006) HydroSHEDS Technical Documentation. World Wildlife Fund US, Washington, DC, USA [www document]. URL http://hydrosheds.cr.usgs.gov

Natura (2007) Plano de desenvolvimento sustentável junto as comunidades do Médio Juruá. Report. CARE Brazil and Natura, São Paulo, Brazil.

Nepstad, D., McGrath, D., Alencar, A., Barros, A.C., Carvalho, G., Santilli, M. \& Diaz, M.D.V. (2002) Frontier governance in Amazonia. Science 295: 629-631.

Newton, P., Nichols, E.S., Endo, W. \& Peres, C.A. (2011a) Consequences of actor level livelihood heterogeneity for additionality in a tropical forest payment for environmental services programme with an undifferentiated reward structure. Global Environmental Change doi: 10.1016/j.gloenvcha.2011.10.006

Newton, P., Watkinson, A.R. \& Peres, C.A. (2011b) Determinants of yield in a non-timber forest product: Copaifera oleoresin in Amazonian extractive reserves. Forest Ecology and Management 261: 255-264.

Pacheco, P. (2009) Smallholder livelihoods, wealth and deforestation in the eastern Amazon. Human Ecology 37: 27-41.

Parry, L., Day, B., Amaral, S. \& Peres, C.A. (2010a) Drivers of rural exodus from Amazonian headwaters. Population and Environment 32: 137-176.

Parry, L., Peres, C. A., Day, B. \& Amaral, S. (2010b) Ruralurban migration brings conservation threats and opportunities to Amazonian watersheds. Conservation Letters 3(4): 251-259.

Peres, C.A., Baider, C., Zuidema, P.A., Wadt, L.H.O., Kainer, K.A., Gomes-Silva, D.A.P., Salomao, R.P., Simoes, L.L., Franciosi, E.R.N., Valverde, F.C., Gribel, R., Shepard, G.H., Kanashiro, M., Coventry, P., Yu, D.W., Watkinson, A.R. \& Freckleton, R.P. (2003) Demographic threats to the sustainability of Brazil nut exploitation. Science 302: 2112-2114.

Projeto RADAMBRASIL (1977) Levantamento de recursos naturais: folha SB. 19 Juruá. Report. Ministério das Minas e Energia, Rio de Janeiro, Brazil.

R Development Core Team (2010) R: A Language and Environment for Statistical Computing. Vienna, Austria: R Foundation for Statistical Computing [www document]. URL http://www.Rproject.org/

Rodrigues, A.S.L., Ewers, R.M., Parry, L., Souza, Jr., C., Verissimo, A. \& Balmford, A. (2009) Boom-and-bust development patterns across the Amazon deforestation frontier. Science 324: 1435-1437.

Ruiz-Perez, M., Almeida, M., Dewi, S., Costa, E.M.L., Pantoja, M.C., Puntodewo, A., Postigo, A.D. \& de Andrade, A.G. (2005) Conservation and development in Amazonian extractive reserves: the case of Alto Jurua. Ambio 34: 218-223.

Ruiz-Pérez, M., Belcher, B., Achdiawan, R., Alexiades, M., Aubertin, C., Caballero, J., Campbell, B., Clement, C., Cunningham, A., Fantini, A., de Foresta, H., García Fernández, C., Gautam, K.H., Hersch Martínez, P., de Jong, W., Kusters, K., Kutty, M.G., López, C., Fu, M., Martínez Alfaro, M.A., Nair, T.K.R., Ndoye, O., Ocampo, R., Rai, N., Ricker, M., Schreckenberg, K., Shackleton, S., Shanley, P., Sunderland, T. \& Youn, Y. (2004) Markets drive the specialisation strategies of forest peoples. Ecology and Society 9: 4. 
Salisbury, D.S. \& Schmink, M. (2007) Cows versus rubber: changing livelihoods among Amazonian extractivists. Geoforum 38: 12331249.

Santos, G.M., Ferreira, E.J.G. \& Zuanon, J.A.S. (2006) Peixes comerciais de Manaus. Report. Ibama/AM, ProVárzea, Manaus, Brazil.

Schwartzman, S. (1989) Extractive reserves: the rubber tappers' strategy for sustainable use of the Amazon rain forest. In: Fragile lands of Latin America: the Research for Sustainable Uses, ed. J. O. Browder, pp. 151-163. Boulder, CO, USA: Westview Press.

SDS (2010) Plano de gestão da Reserva de Desenvolvimento Sustentavel de Uacari. Série Técnica Planos de Gestão, Secretaria de Estado do Meio Ambiente e Desenvolvimento Sustentàvel, Carauari, Brazil.
Stoian, D. (2005) Making the best of two worlds: rural and periurban livelihood options sustained by nontimber forest products from the Bolivian Amazon. World Development 33: 1473-1490.

Takasaki, Y., Barham, B.L. \& Coomes, O.T. (2001) Amazonian peasants, rain forest use, and income generation: the role of wealth and geographical factors. Society and Natural Resources 14: 291308.

Ticktin, T. (2004) The ecological implications of harvesting nontimber forest products. Fournal of Applied Ecology 41: 11-21.

Vadjunec, J.M. \& Rocheleau, D. (2009) Beyond forest cover: land use and biodiversity in rubber trail forests of the Chico Mendes Extractive Reserve. Ecology and Society 14: 29.

Viana, V. (2008) Bolsa Floresta (Forest Conservation Allowance): an innovative mechanism to promote health in traditional communities in the Amazon. Estudos Avançados 22: 64. 